\title{
Hubungan Karakteristik Balita dan Kebiasaan Merokok Anggota Keluarga di Rumah dengan Kejadian ISPA
}

\section{Relationship of Characteristics of Children and Smoking Habits of Family Members at Home with Acute Respiratory Infection (ARI)}

\author{
Gumanti*, Nurmaini, Silaban Gerry \\ Fakultas Kesehatan Masyarakat, Universitas Sumatera Utara, Indonesia
}

(*gumantimanalu21@gmail.com Hp.085297533410)

\begin{abstract}
ABSTRAK
Penyakit Infeksi saluran pernapasan akut berada diurutan pertama dari sepuluh penyakit terbanyak di wilayah kerja Puskesmas Terjun, dimana balita merupakan penderita ISPA terbanyak yang mendapat pelayanan kesehatan. Tujuan penelitian untuk menganalisis hubungan karakteristik balita (umur, status ASI serta status Immunisasi) dan kebiasaan merokok angota keluarga di rumah dengan kejadian ISPA pada balita. Jenis penelitian observasional analitik dengan desain Cross Sectional. Besar sampel 100 anak balita yang berumur $<5$ tahun, distribusi sampel secara proposional, cara pengambilan data purposive sampling. Uji statistik yang digunakan adalah uji che square. Hasil penelitian yaitu kelompok umur balita $\geq 12$ Bulan (12 - 59 bulan) sebesar 78\%, Mendapat ASI sebesar $71 \%$, status imunisasi tidak lengkap sebesar 59\%, terdapat Kebiasaan Merokok Anggota Keluarga di rumah sebesar $51 \%$, dan ISPA sebesar 34\%. Uji Chi-square menunjukkan faktor yang berhubungan signifikan terhadap kejadian ISPA yaitu umur balita $\mathrm{p}$ value $=0,041$ dengan $\mathrm{PR}=2,329(95 \% \mathrm{CI}=1,122-4,834)$ dan kebiasaan merokok anggota keluarga di rumah $\mathrm{p}$ value $=0,029$, dengan $\mathrm{PR}=1,595(95 \% \mathrm{CI}=1,107$ 2,296). Kesimpulan yaitu ada hubungan signifikan antara umur balita dan kebiasaan merokok anggota keluarga di rumah dengan kejadian ISPA pada balita di wilayah kerja Puskesmas Terjun.
\end{abstract}

Kata kunci : Kejadian ISPA, Umur, Merokok, Balita,

\section{ABSTRACT}

Acute respiratory infections are the first of the ten most common diseases in the Plunge Community Health Center work area, where toddlers are the most sufferers of ARI who receive health services. The purpose of this study was to analyze the relationship between the characteristics of children under five (age, breastfeeding status and immunization status) and smoking habits of family members at home with the incidence of ARI in children under five. This type of research is analytic observational with a cross sectional design. The sample size is 100 children under 5 years old, the sample distribution is proportional, the data collection method is purposive sampling. The statistical test used is the che square test. The results of the study were that the age group of toddlers 12 months (12 -59 months) was $78 \%$, received breast milk by $71 \%$, incomplete immunization status was $59 \%$, there were smoking habits of family members at home by $51 \%$, and ARI by $34 \%$. The Chi-square test showed factors that were significantly related to the incidence of ARI, namely the age of toddlers $p$ value $=0.041$ with $P R=2.329$ $(95 \% \mathrm{CI}=1.122-4.834)$ and smoking habits of family members at home $\mathrm{p}$ value $=0.029$, with $\mathrm{PR}=$ $1.595(95 \% \mathrm{CI}=1.107-2.296)$. The conclusion of this study is that there is a significant relationship between the age of the toddler and the smoking habit of family members at home with the incidence of ARI in children under five in the work area of the Terjun Community Health Center.

Keywords : The incidence of ARI, age, smoking, toddlers https://doi.org/10.33860/jik.v15i2.479

(C) 2021 by the authors. Submitted for possible open access publication under the terms and conditions of the Creative Commons Attribution (CC BY SA) license (https://creativecommons.org/licenses/by-sa/4.0/). 


\section{PENDAHULUAN}

Infeksi saluran pernapasan akut (ISPA) adalah penyakit saluran pernapasan akut yang disebabkan oleh agen infeksius yang ditularkan dari manusia ke manusia dengan gejala antara lain demam, batuk, nyeri tenggorok, coryza (pilek), sesak napas, mengi atau kesulitan bernapas ${ }^{1}$. Infeksi saluran pernapasan akut (ISPA) adalah salah satu penyebab utama kematian dan kesakitan penyakit menular di dunia. Angka kematian di dunia. penyakit ini menyumbang $16 \%$ dari seluruh kematian anak dibawah usia 5 tahun, yang menyebabkan kematian pada 920.136 balita, atau lebih dari 2.500 per hari, atau perkirakan 2 anak balita meninggal setiap menit pada tahun $2015^{2}$.

Angka prevalensi infeksi saluran pernapasan akut (ISPA) pada balita untuk Indonesia sebesar 7,8 \%, sedangkan prevalensi ISPA pada balita menurut Propinsi, tertinggi pada Propinsi Bengkulu 14,0 \% diikuti Propinsi Jawa Timur 12,9\% dan Propinsi Nusa Tenggara Timur $12,6 \%$. Propinsi yang angka prevalensi ISPA pada balita terendah pada Propinsi Bangka Belitung 2,1\%, untuk Propinsi Sumatera Utara angka prevalensi ISPA pada balita sebesar $3,7 \%{ }^{3}$.

Faktor risiko yang berhubungan dengan kejadian ISPA terbagi atas faktor intrinsik dan faktor ekstrinsik. Faktor intrinsik meliputi umur, jenis kelamin, status gizi, Berat Badan Lahir Rendah (BBLR), status imunisasi, pemberian ASI dan pemberian vitamin A. Faktor ekstrinsik seperti kondisi fisik lingkungan rumah meliputi kepadatan hunian, polusi udara, ventilasi, asap rokok, penggunaan bahan bakar, serta faktor ibu baik pendidikan, umur maupun perilaku ibu ${ }^{4}$.

Sesuai data laporan tahunan dari Wilayah Kerja Puskesmas Terjun, penyakit ISPA berada diurutan pertama dari sepuluh penyakit terbanyak di Puskesmas Terjun. Selama Tahun 2017 sampai dengan Tahun 2018, menunjukkan ada peningkatan jumlah kunjungan balita pasien penderita ISPA yang mendapat pelayanan kesehatan di Wilayah Kerja Puskemas Terjun. Jumlah penderita ISPA pada balita tahun 2017 sebanyak 1687 penderita, meningkat menjadi 2101penderita pada tahun 2018. ${ }^{5}$.

Tujuan penelitian untuk menganalisis hubungan antara karakteristik balita yakni variabel umur, status ASI, status Immunisasi dan faktor dan kebiasaan merokok anggota keluarga di rumah dengan kejadian ISPA pada balita.

\section{METODE PENELITIAN}

Jenis penelitian ini adalah observasional analitik dengan desain penelitian potong lintang (Cross Sectional). Lokasi penelitian di 3 (tiga) Kelurahan di Kecamatan Medan Marelan di Kota Medan yakni Kelurahan Terjun, Kelurahan Paya Pasir dan Kelurahan Labuhan Deli, pemilihan lokasi adanya pertimbangan peningkatan jumlah kunjungan pasien penderita ISPA pada balita di Puskesmas Terjun. Jumlah populasi balita 6916 jiwa dengan besar sampel 100 anak balita dengan umur balita dibawah 5 tahun, cara pengambilan data dengan purposive sampling ${ }^{6}$.

Pengumpulan data yaitu menggunakan kuesioner untuk mendapatkan data umur, status ASI, Status Imunisasi, Kebiasaan merokok anggota keluarga di rumah, dan informasi kejadian ISPA.

Analisa data mengunakan analisa univariate, analisa bivariat dengan uji Chi square dengan tingkat signifikansi $p<0,05$ dan menggunakan program SPSS.

\section{HASIL}

Hasil penelitian didapatkan informasi distribusi responden untuk umur balita diketahui umur balita $<12$ bulan sebanyak 22 $(22 \%)$ balita, dan umur balita $\geq 12$ bulan berjumlah 78 (78\%) balita . Distribusi status ASI, balita yang tidak mendapat ASI berjumlah $29(29 \%)$ balita (, dan balita yang mendapat ASI berjumlah $71(71 \%)$ balita. Distribusi status imunisasi diketahui balita yang tidak mendapat immunisasi tidak lengkap berjumlah 59 (59\%) balita, dan balita yang mendapat immunisasi lengkap berjumlah 41 (41\%) balita. Distribusi ada kebiasaan merokok anggota keluarga di rumah sebesar 51 (51\%) orang dan tidak adanya kebiasaan merokok anggota keluarga di rumah berjumlah $49(49 \%)$ orang. Distribusi balita yang mengalami kejadian ISPA berjumlah 34 (34\%) balita dan tidak mengalami kejadian ISPA berjumlah $66(66 \%)$ balita (tabel 1).

Tabel 2 menunjukkan bahwa variabel yang memiliki hubungan signifikan dengan kejadian ISPA yaituumur dengan nilai $\mathrm{p}=0,041$ dan kebiasaan merokok anggota keluarga di rumah dengan nilai $\mathrm{p}=0,029$. 
Tabel 1. Distribusi Frekuensi Karakteristik Balita, Faktor Kebiasaan Merokok Anggota Keluarga, dan Kejadian ISPA pada Balita di Wilayah Kerja Puskesmas Terjun

\begin{tabular}{lcc}
\hline Karakteristik balita \& Prilaku Merokok & $\mathbf{n = 1 0 0}$ & $\mathbf{\%}$ \\
\hline Umur & & 22 \\
$\quad$ <12 Bulan (0-11 bulan) & 22 & 78 \\
$\geq 12$ Bulan (12-59 bulan) & 78 & 29 \\
\hline Status ASI & 29 & 71 \\
$\quad$ Tidak Mendapat ASI & 71 & 59 \\
Mendapat ASI & & 41 \\
\hline Status Imunisasi & 59 & \\
Tidak Lengkap & 41 & 51 \\
Lengkap & & 49 \\
\hline Kebiasaan Merokok Anggota Keluarga di rumah & 51 & \\
Ada & 49 & 34 \\
Tidak Ada & & 66 \\
\hline Kejadian ISPA & 34 & \\
Ya & 66 & \\
Tidak & & \\
\hline
\end{tabular}

Tabel 2 Hubungan antara Karakteristik Balita dan Faktor Perilaku Kebiasaan Merokok Anggota Keluarga di Rumah dengan Kejadian ISPA pada Balita di Wilayah Kerja Puskesmas Terjun.

\begin{tabular}{|c|c|c|c|c|c|c|c|c|}
\hline \multirow{3}{*}{ Variabel } & \multicolumn{6}{|c|}{ Kejadian ISPA } & \multirow{3}{*}{$\begin{array}{c}\text { p. } \\
\text { value }\end{array}$} & \multirow{3}{*}{$\begin{array}{c}\text { RP } \\
(95 \% \mathrm{CI})\end{array}$} \\
\hline & \multicolumn{2}{|c|}{ Ya } & \multicolumn{2}{|c|}{ Tidak } & \multicolumn{2}{|c|}{ Total } & & \\
\hline & $\mathbf{N}$ & $\%$ & $\mathbf{n}$ & $\%$ & $\mathbf{N}$ & $\%$ & & \\
\hline \multicolumn{8}{|l|}{ Umur } & \multirow{3}{*}{$\begin{array}{c}2,329 \\
(1,122-4,834)\end{array}$} \\
\hline$<12$ Bulan & 12 & 54,5 & 10 & 45,5 & 22 & 100,0 & 0,041 & \\
\hline$\geq 12$ Bulan & 22 & 28,2 & 56 & 71,8 & 78 & 100,0 & & \\
\hline \multicolumn{8}{|l|}{ Status ASI } & \multirow{3}{*}{$\begin{array}{c}1,022 \\
(0,536-1,946)\end{array}$} \\
\hline Tidak Mendapat ASI & 10 & 34,5 & 19 & 65,5 & 29 & 100,0 & \multirow{2}{*}{1,000} & \\
\hline Mendapat ASI & 24 & 33,8 & 47 & 66,2 & 71 & 100,0 & & \\
\hline \multirow{3}{*}{$\begin{array}{l}\text { Status Imunisasi } \\
\text { Tidak Lengkap } \\
\text { Lengkap }\end{array}$} & & & & & & & & \multirow{3}{*}{$\begin{array}{c}1,240 \\
(0,900-1,708)\end{array}$} \\
\hline & 23 & 39,0 & 36 & 61,0 & 59 & 100,0 & 0295 & \\
\hline & 11 & 26,8 & 30 & 73,2 & 41 & 100,0 & 0,295 & \\
\hline \multicolumn{8}{|c|}{ Kebiasaan Merokok Anggota Keluarga di rumah } & \multirow{3}{*}{$\begin{array}{c}1,595 \\
(1,107-2,296)\end{array}$} \\
\hline Ada & 23 & 45,1 & 28 & 54,9 & 51 & 23 & \multirow{2}{*}{0,029} & \\
\hline Tidak Ada & 11 & 22,4 & 38 & 77,6 & 49 & 100,0 & & \\
\hline
\end{tabular}

\section{PEMBAHASAN}

\section{Hubungan Umur Balita dengan Kejadian ISPA pada Balita}

Hasil analisis hubungan umur balita dengan kejadian ISPA berdasar uji statistik diperoleh $p$ value $=0,041 \quad(p<0,05)$ sehingga dapat diketahui bahwa ada hubungan yang bermakna antara umur balita dengan kejadian ISPA pada balita di wilayah kerja Puskesmas Terjun. Variabel umur balita memiliki nilai $P R$ $=2,329(95 \% C I=1,122-4,834)$, ini artinya balita yang berumur $<12$ bulan memiliki proporsi 2,329 kali lebih besar untuk terjadinya ISPA dibandingkan dengan balita yang berumur $\geq 12$ bulan. Mekanisme hubungan usia balita dengan kejadian ISPA disebabkan oleh karena mekanisme faktor immunitas balita yang belum terbentuk sempurna ${ }^{7}$. Penelitian lain menunjukkan bahwa kejadian ISPA atas terbanyak adalah laki-laki, pada kelompok balita, dengan status gizi baik, dan umumnya bertempat tinggal di daerah rural ${ }^{8}$.

Kemudian penelitian lainnya menunjukkan ada hubungan antara karakteristik anak balita menurut umur dengan kejadian ISPA dengan $p$ value untuk variabel umur sebesar 0,013 atau nilai $p$ kurang dari 0,05 dan mayoritas umur anak balita yang terkena ISPA adalah 1-2 tahun sebesar 26,0\%9 .

Penelitian di Puskesmas Porong Kabupaten Sidoarjo diperoleh kelompok usia terbanyak pada usia 1-5 tahun sebesar $70 \%{ }^{10}$. Kejadian ISPA atas lebih sering terjadi pada 
anak berusia 2-5 tahun karena pada usia tersebut anak sudah banyak terpapar dengan lingkungan luar dan kontak dengan penderita ISPA lainnya sehingga memudahkan anak untuk menderita ISPA $^{10}$.

\section{Hubungan Status ASI dengan Kejadian ISPA pada Balita}

Hasil analisis antara hubungan status ASI dengan kejadian ISPA pada balita berdasarkan uji statistik diperoleh $p$ value $=1,000 \quad(p>0,05) \quad$ sehingga diketahui bahwa tidak ada hubungan bermakna antara status ASI dengan kejadian ISPA pada balita di Wilayah kerja Puskesmas Terjun. Status ASI memiliki nilai $P R=1,022(C I 95 \%=0,536-$ 1,946). Tidak adanya hubungan status ASI dengan kejadian ISPA pada balita hal ini dipengaruhi masih banyaknya ibu balita di wilayah kerja Puskesmas Terjun yang memberikan ASI kepada balita sebesar $71 \%$ dibandingkan dengan ibu balita tidak memberi ASI kepada balita sebesar $29 \%$. Pemberian ASI untuk balita bermanfaat bagi sistem kekebalan tubuh semakin kuat sehingga tidak mudah terserang penyakit infeksi saluran pernapasan akut $^{11}$.

Penelitian lainnya menunjukkan bahwa tidak ada hubungan antara ASI eksklusif dengan kejadian ISPA pada balita di wilayah kerja Puskesmas Ranotana Weru Kota Manado $^{12}$. Pemberian ASI non-eksklusif dapat meningkatkan kemungkinan efek buruk dari perokok pasif rumah tangga, seperti ISPA pada anak balita ${ }^{13}$. Temuan risiko ISPA yang lebih tinggi di antara anak-anak yang tidak diberi ASI eksklusif dapat disebabkan oleh penurunan kekebalan pada aanak-anak ini ${ }^{14}$.

Air Susu Ibu (ASI) merupakan makanan bayi yang paling sempurna, bersih dan sehat serta praktis karena mudah diberikan setiap saat. ASI dapat mencukupi kebutuhan gizi bayi untuk tumbuh kembang dengan normal sampai berusia 6 bulan. ASI eksklusif adalah pemberian ASI eksklusif kepada bayi sampai umur 6 bulan tanpa mamberikan makanan atau cairan lain ${ }^{15}$. ASI berperan dalam memproteksi tubuh dari penyakit karena ASI mengandung Imunoglobulin A ( $\operatorname{IgA}$ ) yang akan bereaksi dengan molekul adhesi dari patogen yang masuk ke dalam tubuh sehingga mencegah adheheren dan kolonisasi patogen tersebut dalam sel pejamu ${ }^{16}$.

\section{Hubungan Status Immunisasi dengan Kejadian ISPA pada Balita}

Hasil analisis hubungan status imunisasi dengan kejadian ISPA pada balita berdasarkan uji statistik diperoleh nilai $p=0,295$ $(p>0,05)$ sehingga diketahui bahwa tidak ada hubungan antara status imunisasi dengan kejadian ISPA pada balita di Wilayah kerja Puskermas Terjun. Tidak adanya hubungan status immunisasi terhadap kejadian pada balita ini menunjukkan kesadaran dan kepedulian ibu balita di wilayah kerja Puskesmas Terjun akan pentingnya pemberian immunisasi pada balita di Puskesmas Terjun sudah baik. Immunisasi adalah suatu cara meningkatkan kekebalan tubuh seseorang secara aktif terhadap suatu antigen, sehingga bila kelak ia terpapar pada antigen yang serupa, tidak terjadi penyakit. Hal ini menunjukan bahwa pemberian imunisai dasar yang lengkap sesuai dengan umurnya maka risiko penyakit ISPA akan semakin kecil.

Salah satu pencegahan ISPA adalah imunisasi $^{17}$, pemberian imunisasi sangat diperlukan baik pada anak-anak maupun orang dewasa. Imunisasi dilakukan untuk menjaga kekebalan tubuh supaya tidak mudah terserang berbagai macam penyakit yang disebabkan oleh virus/ bakteri. Imunisasi bermanfaat untuk mencegah berbagai jenis penyakit infeksi seperti Polio, TBC, Difteri, Pertusis, Tetanus, Hepatitis $B$ dan Campak. Imunisasi juga dapat mencegah kematian demi akibat penyakitpenyakit tersebut. Penyakit yang tergolong ISPA yang dapat dicegah dengan imunisasi adalah difteri dan batuk rejan ${ }^{18}$.

Balita telah menerima imunisasi dasar lengkap balita masih beresiko mengalami ISPA karena terdapat juga beberapa faktor yang dapat mempengaruhi kejadian ISPA yaitu paparan dari virus, bakteri dan status gizi balita ${ }^{19}$. Kejadian penyakit ISPA yang berulang pada balita dapat juga diakibatkan karena pengetahuan ibu mengenai penyakit, pencegahan penyakit dan cara pemeliharaan kesehatan yang masih kurang ${ }^{19}$.

\section{Hubungan Kebiasaan Merokok Dengan Kejadian ISPA pada Balita.}

Hasil analisis hubungan kebiasaan merokok anggota keluarga di rumah dengan kejadian ISPA diperoleh $p$ value $=0,029$ $(p<0,05)$, sehingga diketahui bahwa ada hubungan antara kebiasaan merokok anggota keluarga di rumah dengan kejadian ISPA pada balita di wilayah kerja Puskesmas Terjun Kota Medan. Kebiasaan merokok anggota keluarga di rumah memiliki nilai $P R=1,595(95 \% C I=$ 1,107-2,296) ini artinya adanya kebiasaan anggota keluarga yang merokok di rumah 
memiliki proporsi 1,595 kali lebih besar untuk terjadinya ISPA dibandingkan dengan tidak adanya kebiasaan anggota keluarga yang merokok di rumah.

Hasil observasi peneliti mendapati masih banyak orangtua balita di wilayah kerja Puskesmas Terjun memiliki kebiasaan merokok di dalam rumah. Asap rokok dari orang tua atau penghuni rumah yang satu atap dengan balita merupakan bahan pencemaran dalam ruang tempat tinggal yang serius serta akan menambah resiko kesakitan dari bahan toksik pada anak-anak ${ }^{20}$. Paparan yang terus menerus akan menimbulkan gangguan pernapasan terutama memperberat timbulnya infeksi saluran pernafasan akut (ISPA) dan gangguan paru-paru pada saat dewasa ${ }^{13,21}$. Semakin banyak rokok yang dihisap oleh keluarga semakin besar memberikan resiko terhadap kejadian ISPA, khususnya apabila merokok dilakukan oleh ibu balita ${ }^{21}$. Anak-anak yang orang tuanya perokok lebih rentan terkena penyakit saluran pernapasan seperti $f l u$, asma pnemonia dan penyakit saluran pernapasan lainnya ${ }^{22}$..

\section{KESIMPULAN DAN SARAN}

Variable yang memiliki hubungan yang signifikan dengan kejadian ISPA pada balita di Puskesmas Terjun adalah umur balita ( $p$ value $=0,041)$ dan kebiasaan merokok anggota keluarga di rumah ( $p$ value $=0,029$ ).

Saran bagi petugas kader posyandu agar dapat memotivasi bagi ibu yang memiliki anak balita di wilayah kerja Puskesmas Terjun agar membawa anaknya ke posyandu rutin sekali sebulan, bagi orang tua balita diharapkan agar tidak merokok di dalam rumah sehingga lingkungan rumah bebas dari paparan asap rokok

\section{DAFTAR PUSTAKA}

1. WHO. Pencegahan dan pengendalian infeksi saluran pernapasan akut (ISPA) yang cenderung menjadi epidemi dan pandemi di fasilitas pelayanan kesehatan: Pedoman Interim WHO. Jenewa: World Health Organization; 2007.

2. WHO. The Global Impact of Respitory Dieases. Gord Publication the Global Impact of Respitory diseasesWorld Health Deases. (2017).

3. Dasar RK. Hasil Utama Riset Kesehatan Dasar (RISKESDA). Jakarta; 2018.

4. Ramadhaniyanti, N.,Budiyono N. FaktorFaktor Risiko Lingkungan Rumah dan Prilaku yang Berhubungan dengan Kejadian ISPA pada Balita di Kelurahan Kuningan Kecamatan Semarang Utara. 2015;vol.3.

5. Dinas Kesehatan Kota Medan. Laporan Tahunan Kegiatan Tahun 2018. Kota Medan; 2018.

6. Riyanto A. Aplikasi Metodologi Penelitian Kesehatan. Edisi-2. Penerbit Kuha Modika Yogyakarta; 2015.

7. Iskandar A, Tanjuwjiaya S, Yuniarti L. Hubungan jenis kelamin dan usia anak satu tahun sampai lima tahun dengan kejadian infeksi saluran pernapasan akut (ISPA). Global Medical and Health Communication. 2015;3(1):1-6.

8. Maharani D, Yani FF, Lestari Y. Profil Balita Penderita Infeksi Saluran Nafas Akut Atas di Poliklinik Anak RSUP DR. M. Djamil Padang Tahun 2012-2013. Jurnal Kesehatan Andalas. 2017 Jul 20;6(1):152-7.

9. Maulidiyah, D., Retno A. Hubungan Usia Balita dan Sanitasi Fisik Rumah dengan Kejadian ISPA di Desa Tumapel Kabupaten Mojokerto. 2017;

10. Fitriawati D. Hubungan antara tingkat keparahan ISPA pada balita usia 0-5 tahun dengan persepsi orang tua terhadap kerentanan anak (prental perception of child vulnerability) di Puskesmas Porong Kabupaten Sidoarjo [Skripsi]. [Malang]: Universitas Brawijaya; 2013.

11. Palmeira P, Carneiro-Sampaio M. Immunology of breast milk. Rev Assoc Med Bras. 2016 Sep;62:584-93.

12. Cheryn, D P. Faktor-Faktor yang Berhubungan dengan Kejadian Infeksi Saluran Pernapasan Akut (ISPA) pada Balita di Wilayah Kerja Puskesmas Ranotana Weru Kota Manado. 2015;(fkm Universitas Sam Ratulangi Manado).

13. Thapa P, Pandey AR, Dhungana RR, Bista B, Thapa B, Mishra SR. Risk of ARI among Non-exclusively Breastfed Under-Five Passive Smoker Children: A Hospital-Based Cross-sectional Study of Nepal. Front Public Health. 2016 Feb 23;4:23.

14. Hanson LA. Human milk and host defence: immediate and long-term effects. Acta Paediatr Suppl. 1999 Aug;88(430):42-6.

15. Kementerian Kesehatan RI. Situasi dan Analisis ASI Eksklusif. Jakarta; 2014.

16. Hidayatullah LM, Helmi Y, Aulia $\mathrm{H}$. Hubungan Antara Kelengkapan Imunisasi Dasar dan Frekuensi Infeksi Saluran Pernapasan Akut (ISPA) pada Balita yang Datang Berkunjung ke Puskesmas Sekip Palembang 2014. Jurnal Kedokteran dan Kesehatan. 2016;3(3):182-93.

17. Cattaneo A. Current role of vaccination in preventing acute respiratory infections in 
children in developing countries. Monaldi Arch Chest Dis. 1994 Feb;49(1):57-60.

18. Kemenkes RI. Peraturan Menteri Kesehatan Republik Indonesia Nomor 42 Tahun 2013 Tentang Penyelenggaraan Imunisasi Dengan Rahmat Tuhan Yang Maha Esa Menteri Kesehatan Republik Indonesia. 2013;

19. Sambominanga PS, Ismanto AY, Onibala F. Hubungan pemberian imunisasi dasar lengkap dengan kejadian penyakit ISPA berulang pada balitas di Puskesmas Ranotana Weru Kota Manado. Jurnal Keperawatan. 2014 Aug $8 ; 2(2): 1-7$.

20. Dumilah R. Determinan Kebiasaan Merokok Kepala Keluarga Pada Balita Penderita Ispa Di Desa Karangharja. Asuhan Kesehatan: Jurnal Ilmiah Ilmu Kebidanan dan Keperawatan. 2016 Jan 10;7(1):31-8.

21. Jones LL, Hashim A, McKeever T, Cook DG, Britton J, Leonardi-Bee J. Parental and household smoking and the increased risk of bronchitis, bronchiolitis and other lower respiratory infections in infancy: systematic review and meta-analysis. Respiratory Research. 2011 Dec 1;12(1):5.

22. Cinar N, Dede C, Cevahir R, Sevimli D. Smoking status in parents of children hospitalized with a diagnosis of respiratory system disorders. Bosn J Basic Med Sci. 2010 Nov;10(4):319-22. 